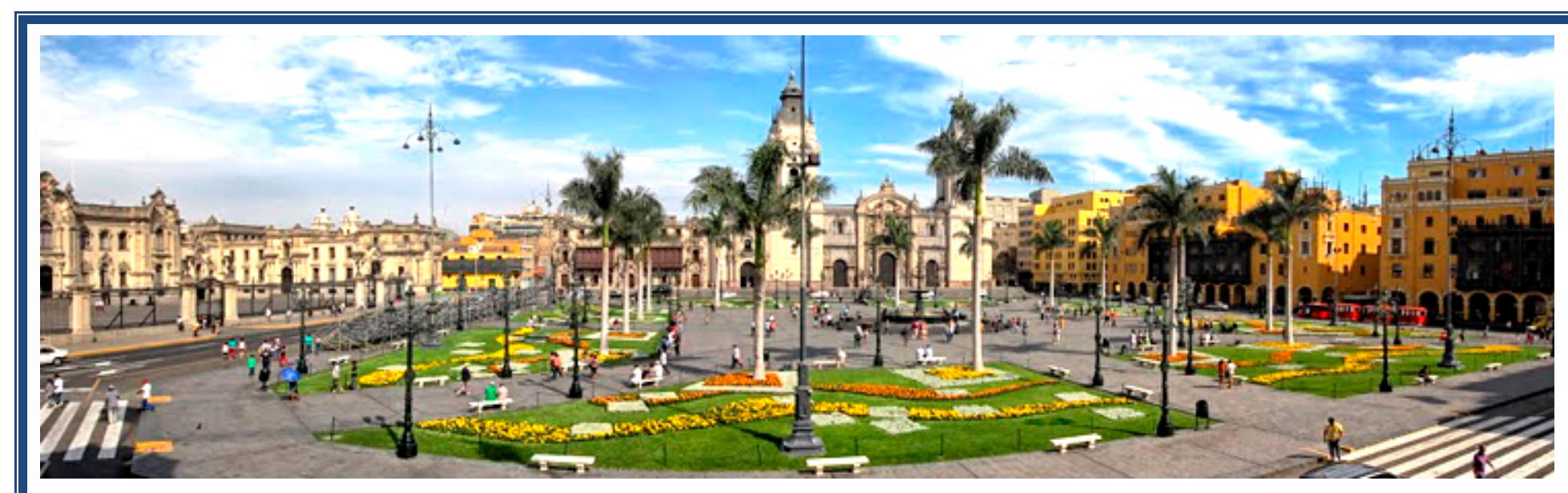

\title{
ACTA OF LIMA
}

Within the FRAMEWORK OF THE MEETING OF NATIONAL ACADEMIES OF MEdicine OF Bolivia, Chile, Colombia, Paraguay and Peru on Person Centered Medicine and HeAlth, that tOOK Place at the Medical College of PERU IN Lima City ON DECEMBER 13, 2014 , AND WITH THE PARTICIPATION OF DISTINGUISHED REPRESENTATIVES OF MEDICAL AND UNIVERSITY ORGANIZATIONS AND THE ACADEMIC COMMUNITY OF PERU, THE FOLLOWING AGREEMENTS WERE MADE:

1. TO APPRECIATE THE PROMISING EXPERIENCES OF LATIN AMERICAN ACADEMIES OF MEDICINE FOR THE DEVELOPMENT OF PERSON-CENTERED MEDICINE.

2. TO RECOGNIZE THE DEVELOPMENT OF AN ACTIVE PROGRAM OF PERSON CENTERED MEdicine WITHIN THE NATIONAL ACADEMY OF MEDICINE OF PERU AND ITS COLLABORATIVE WORK WITH MEDICAL AND OTHER HEALTH INSTITUTIONS REGARDING CLINICAL CARE, EDUCATION, RESEARCH AND PUBLIC HEALTH .

3. To Endorse the Declaration of Buenos Aires on latin AMERICAN Humanism AND SCIENCE FOR PERSON CENTERED MEDICINE, HELD IN BUENOS AIRES DURING THE SECOND INTERNATIONAL CONGRESS OF PERSON CENTERED MEDICINE, INCLUdING ITS HISTORICAL, CULTURAL, ECOLOGICAL AND PROFESSIONAL FOUNDATIONS, AND ITS SEVEN RECOMMENDATIONS ON CONCEPTUALIZATION, EDUCATION, CLINICAL RESEARCH, HEALTH POLICY, AND INTER-INSTITUTIONAL AND INTER-SECTORAL COLLABORATION.

4. TO PROPOSE THE ORGANIZATION OF A LATIN AMERICAN NETWORK FOR CULTIVATING PERSON CENTERED MEDICINE SPONSORED BY THE LATIN AMERICAN ACADEMIES OF MEDICINE IN COLLABORATION WITH UNIVERSITIES, MEDICAL SCHOOLS, MINISTRIES AND OTHER LATIN AMERICAN HEALTH INSTITUTIONS AND IN CONNECTION WITH THE international College of PERson Centered Medicine.

LIMA, DECEMBER 13, 2014

DR. RODOLFO ARMAS

PRESIDENT

Academia Nacional de Medicina de Chile

Dr. Daniel Elio-Calvo

PRESIDENT

ACAdEMia Nacional de Medicina de Bolivia
DR. OSCAR CODAS

PRESIDENT

Academia Nacional de MEdicina de PARAguay

Dr. JuAn MENdoza VEga

PRESIDENT

ACAdemia Nacional de Medicina de Colombia

Dr. PATRICK WAgNer GRAu

PRESIDENT

ACAdemia Nacional de Medicina del PERÚ 